\title{
高分子の弾性率, 強度の極限
}

\section{梶山千里}

Tisato Kajiyama, 九州大学 工学部

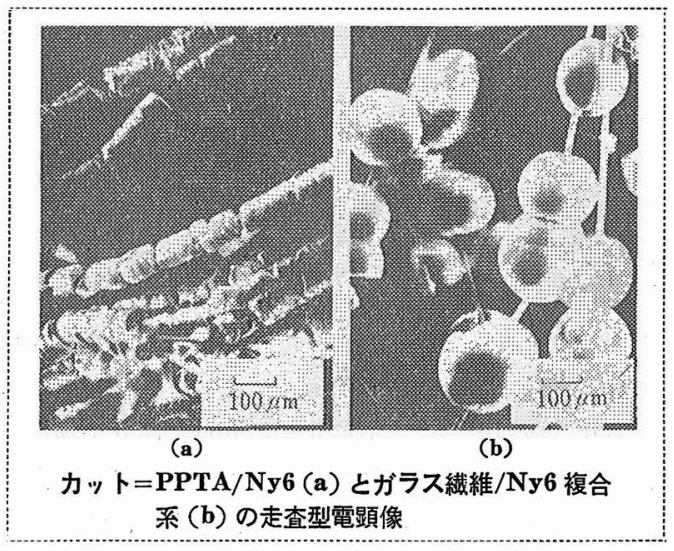

\section{1. は じめに}

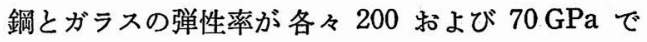
あるのに対し，バルク高分子材料の弾性率は通常数 GPa である.

高分子鎖は共有結合で連結されている結果, 本来, 分子軸方向と分子間方向飞沿って顕著な力学的異方 性を持つ. 分子軸方向の弾性率は鋼のそれに四敨 寸る $200 \sim 300 \mathrm{GPa}$ にる達するが, バルク高分子材料 では高分子本来の力学的特性の数パーセントしか利用 していないことになる. それゆ穴, 高分子材料の強度 と弾性率を高分子鎖の化学結合の本性炕よっ与兄ら れる理論值まで向上させる努力がなされるべきであ る. 理論值近い力学物性を高分子材料澄揮させる ためには，高分子鎖の共有結合力を直接応用すること が必要である，その実現のため，屈曲性高分子に対し ては加工法の改良などの物理的手法と, 剛直性高分子 に対しては主鎖の化学組成変化などの化学的手法を検 討することによって努力がなされてきた．物理的ある いは化学的手法に分類したとは言うものの, 高分子鎖 の極限力学特性を共有結合という化学結合の本性に求 めようとする点で, 基本的には全く同じ概念に基づく ものである.

Ultimate Strength and Modulus of Polymers
高分子に力学的性質の極限を発揮させるためには， 高分子鎖の主鎖方向に均一にひずみないし応力が伝ぱ するように配向高次構造を制御すればよい. 近年, 高 分子鎖の弾性率, 強度の極限性能に関する総説 ${ }^{12 ~ 3)}$ も 多く, 詳しく解説されているので, できるだけ重複を 避けるため, 本稿では, 高分子材料の高弾性率や高強 度を実現するための方法論に重点を置いて解説した い, 高強度, 高弾性率材料の定義はないが, 現在の加 工技術から判断して，理論的飞期待しうる值の $30 \%$ 以上達成されていればこの範疇て入れてもよいであろ 亏.

\section{2. 高分子鎖の強度, 弾性率の極限值}

高分子の主鎖は一般に $\mathrm{C}, \mathrm{N}, \mathrm{O}, \mathrm{S}$ 原子の共有結 合からなる，A-B 結合の場合， A と B 原子の原子間 距離, $r$ の関数として相互作用エネルギー, $U(r)$ を 評価することがでされぱ, 2 原子間の力, $F$ は $F=$ $d U(r) / d r$ 上り求まる. $d F / d r=d^{2} U(r) / d r^{2}=0$ を満

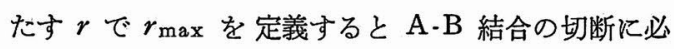
要な力 $F_{\max }=[d U(r) / d r] r_{\max }$ を計算することがで きる. 共有結合によって結ばれている二原子間の相互 作用エネルギー, U(r) はモース関数によって記述す ることができる。

$$
U(\boldsymbol{r})=U_{0}\left[\exp \left\{-2 a\left(r-r_{0}\right)\right\}-2 \exp \left\{-a\left(r-r_{0}\right)\right\}\right]
$$

$U_{0}$ は結合エネルギーで， 2 原子を無限に引き離した 時のポテンシャルエネルギーと A, B 原子の平衡距離 r 0 に括けるポテンシャルエネルギーとの差に対応す

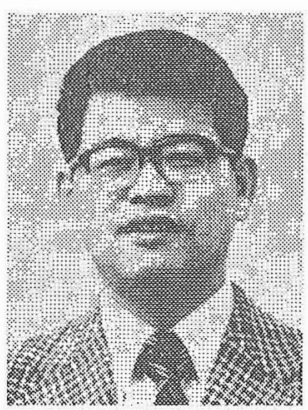

梶山千里 九州大学工学部応用 化学科 (812 福岡市東区箱崎 6) 助教授・工博. Ph. D. ( マサ千 ニーセッッ大)

昭和 39 年九州大学工学部応用 化学科卒, 44 年マサチニーセ ッツ大大学院修了. 同年マサチ ニーセッッ大で Post dectoral fellow, 45 年九大工学部助手, 50 年助教授. 尃門は高分子固 体物性. 
表 1 高分子材料の弾性率と強度

\begin{tabular}{|c|c|c|c|c|c|c|c|}
\hline & & $E_{\mathrm{c} / /{ }^{*}}$ & $E_{\text {(bulk) }} *$ & $\frac{E_{\text {(bulk) }}}{E_{\mathrm{c} / /}}$ & $\sigma_{b}$ (主鎖切断) ${ }^{*}$ & $\sigma_{b(\mathrm{bulk})} *$ & $\frac{\sigma_{b(\mathrm{bulk})}}{\sigma_{b} \text { (主鎖切断) }}$ \\
\hline \multirow{4}{*}{ 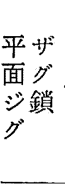 } & (ポリエチレン & $235 \sim 250$ & 142 & 0.52 & 26.5 & 4.7 & 0.18 \\
\hline & ナイロン 6 & 165 & 16.5 & 0.10 & 26.2 & 1.0 & 0.04 \\
\hline & $\begin{array}{l}\text { ポリエチレンテレフタ } \\
\text { レート }\end{array}$ & 108 & 21.4 & 0.20 & & 0.9 & 0.03 \\
\hline & (ポリビニルクロライド & & & & 23.5 & & \\
\hline \multirow{7}{*}{$\begin{array}{l}5 \\
\text { せ } \\
\text { 丸 } \\
\text { 鎖 }\end{array}$} & $\begin{array}{l}\text { (ポリテトラフロオロエ } \\
\text { チレン }\end{array}$ & 153 & & & 19.4 & & \\
\hline & ポリオキシメチレン & 53 & 35 & 0.66 & 37.1 & & \\
\hline & iso-ポリプロピレン & 34 & 25 & 0.74 & 16.2 & 0.95 & 0.06 \\
\hline & ataーポリスチレン & 12 & 4.5 & 0.38 & & & \\
\hline & $\begin{array}{l}\text { ポリ-4ーメチルペンテ } \\
\text { ソ-1 }\end{array}$ & 7 & & & 8.7 & & \\
\hline & $\begin{array}{l}\text { ポリメチルメタクリレ } \\
\text { ート }\end{array}$ & & & & 11.3 & & \\
\hline & ポリブテン-1 & & & & 13.4 & & \\
\hline \multirow{3}{*}{$\begin{array}{l}\text { 剛 } \\
\text { 直 } \\
\text { 分 } \\
\text { 子 }\end{array}$} & $\left\{\begin{array}{c}\text { ホリ }(p \cdot フ ェ=レ ン テ \\
レ フ タ ル ア ト ゙)\end{array}\right.$ & 153 & 132 & 0.86 & $30 \sim 40$ & 3.9 & 0.11 \\
\hline & ポリ（p-ベンズアミド） & 163 & 128 & 0.77 & & & \\
\hline & 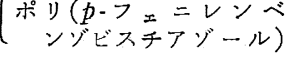 & & 250 & & & 2.4 & \\
\hline
\end{tabular}

* 単位は $\mathrm{GPa}$

る， $a$ は $r_{0}$ に括汁る式 (1) の曲率に関係するパラ メータである. ここで,

$$
\begin{aligned}
& F_{\max }=\frac{U_{0} a}{2} \\
& \left(\frac{d^{2} U}{d r^{2}}\right)_{r=r_{0}}=2 a^{2} U_{0}
\end{aligned}
$$

が成立する.式 (3) は A-B 結合を伸張するときの 力の定数に等しく, 分光学的データから $a$ を評価する ことができる.ここで高分子主鎖中に最も多く存在す る C-C 結合の破断強度を評価してみる、C-C 結合の 伸縮振動の力の定数は $5.2 \mathrm{Ncm}^{-1}$ であり，C-C の結 合エネルギーは， $U_{0}=347 \mathrm{~kJ} \mathrm{~mol}^{-1}$ であるから式 (3) より $a=2.12 \times 10^{8} \mathrm{~cm}^{-1}$ となる， $a$ と $U_{0}$ を式 （2）飞代入すると，C-C 結合を破断する力として $F_{\max }=3.69 \mathrm{MJ} \mathrm{mol}^{-1} \cdot \mathrm{nm}^{-1}$ を得る. ポリエチレン (PE) の C-C 結合の破断応力, $\sigma_{b}$ を計算するために は, C-C 結合連鎖の断面積が必要となる. PE 主鎖の 断面積 $0.182 \mathrm{~nm}^{2}$ を用いると, 破断が主鎖切断起 因する場合には $\sigma_{b}=33.7 \mathrm{GPa}$ となる. 主鎖中に C-N 結合があるときには約 $30 \mathrm{GPa}$ となる。またポリエチ レン㵶維の破断が主鎖間の滑りで起こる場合には $\sigma_{b}$ $=3.7 \mathrm{GPa}$ である.

次化 PE 鎖の理論弾性率を評価してみる. 結晶相 中の $\mathrm{PE}$ 主鎖は主鍞の最も伸び切った平面ジグザグ コンホメーションをとるため; 引張り理論弾性率は 屈曲性高分子のうち最高值となると考学られる。 Treloar ${ }^{4)}$ は分子鎖の変形が分子内の変化のみで生ず るものと仮定して, 分子軸方向の引張り弾性率, $E_{\mathrm{c} / /}$
を計算している. C-C 結合長を $l, C$ C-C-C 結合角を $\alpha$, 分子軸に沿った伸張方向と C-C 結合のなす角を $\theta$ とする $[\theta=(\pi-\alpha) / 2] . n$ 結合からなる分子鎖の 分子軸方向に $F$ なる力をかけをとさの分子軸方向の 全変形量 $\Delta L$ は,

$$
\begin{aligned}
\Delta L & =\Delta(n l \cos \theta) \\
& =n\left(\frac{F}{k_{l}} \cos ^{2} \theta+\frac{F l^{2}}{4 k_{\alpha}} \sin ^{2} \theta\right)
\end{aligned}
$$

ただし， $k_{l}$ と $k_{\alpha}$ は各々 C-C 結合の伸張と变角に対 する力の定数である． $k_{l}$ と $k_{\alpha}$ の単位を一致させるた め, $k_{\alpha}$ を曲げの力の定数, $k_{p}$ 飞変換すると $k_{\alpha}=k_{p} l^{2}$ となる．そこで分子鎖の断面積を $A$ とすると弾性率 $E_{\mathrm{c} / / \text { は }}$

$$
E_{\mathrm{c} / /}=\frac{l \cos \theta}{A}\left(\frac{\cos ^{2} \theta}{k_{l}}+\frac{\sin ^{2} \theta}{4 k_{p}}\right)^{-1}
$$

式（5）に分子パラメータと力の定数を代入すると分

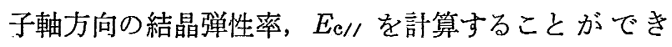
る. $\mathrm{PE}$ 鎖の場合, $E_{\mathrm{c} / /}=180 \sim 316 \mathrm{GPa}$ が報告され ている.ナイロン 66 の場合 $E_{\mathrm{c} / /}=197 \mathrm{GPa}$ である.

Vincent ${ }^{5)}$ は無配向高分子固体膜の臨界引張破断応 力, $\sigma_{b}$ が単位断面積当たりの分子鎖数, $n$ に比例す ることを報告している. この事実は， $\sigma_{b}$ と $n$ の比例 定数に適当な值を選ら゙ことにより, 臨界破断強度を主 鎖切断強度に等しいと和けることを示唆している. 主 鎖が C-C 結合の場合, C-C 結合の切断荷重 $6.1 \times 10^{-9}$ $\mathrm{N}$ と単位断面積当たりの結合数の積より，主鎖切断強 度を予測することができ，それらを表 $10 \sigma_{b}$ (主鋇切断) の欄にまとめてめる。 


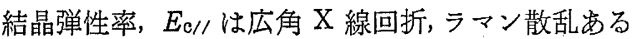
いは中性子散乱法により求められている。単結晶では なくバルク試料から結晶弾性率を正確に評価すること は困難である，しかし，高配向試料を使用することに より，結晶領域之非晶領域に同じ大ささの応力がかか ると仮定すると，荷重と X 線回折より求まる結晶格

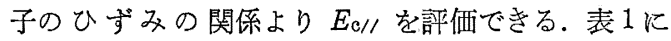

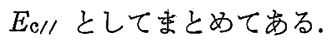

\section{3. バルク高分子材料の力学的極限性能}

表 1 の第 $3 ， 6$ 欄は現在まで報告されている高配向 瀻維試料の最高弾性率 $E_{(\mathrm{bu} 1 \mathrm{k})}$ 之最高強度 $\sigma_{b(\mathrm{bulk})}$ をまとめたものである。ただし， $E_{\left(\mathrm{bu} \mathrm{l}_{\mathrm{k}}\right)}$ と $\sigma_{b(\mathrm{bulk})}$ は 再現よく報告されているものに限放ている. 前者の結

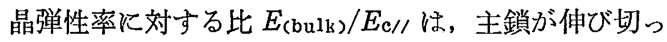
たュンホメーションに近い屈曲性高分子の場合には $0.10 \sim 0.57$ ，らせんコンホメーションをとる場合に は $0.38 \sim 0.74$, 㓮直性高分子の場合には $0.77 \sim 0.86$ であることがわかる．また主鎖切断の理論強度火対す るバルク試料の破断強度の比 $\sigma_{b\left(\mathrm{bu} \mathrm{l}_{\mathrm{k}}\right)} / \sigma_{b}$ (主镍切断) は 屈曲性高分子の場合には 0.03〜0.18 になっている. 表 1 はバルク試料を構成する各高分子鎖が強度や弾性 率汇関して共有結合の持つ力学特性の限界を十分発揮 していないことを示している，平面ジグザグコンホメ ーションの場合よりらせんコンホメーションの場合 の $E_{(\mathrm{bu} 1 \mathrm{k})} / E_{\mathrm{c} / /}$ が一般に大きい. 延伸繰作によりら せん構造が破堎され，かなり伸び切った分子鎖状態と なるためであろう．高分子材料の弾性率や強度を高分 子鎖が本来持っている極限値まで高めるためには，無 限鎖長の高分子鎖を完全配向させ，外力が 分子軸方 向に掛かるよう高次構造を制御させると，その場合の 又可能となる．高分子鎖のバルク凝集特性を考兄る と，完全に配向した分子鎖凝集状態を実現することは 不可能である，そこで，現実には，現在まで開発され てきた加工技術を適用して高分子材料の力学特性をい かに極限値に近づけるかが重要な課題となる.

ここで高分子の配向高次構造と力学特性との関係を 考学てみよう. 高分子配向物の高次構造モデルとして Peterlin モデル6)がある. Peterlin モデルによると， 幅 10〜20 nm のミクロフィブリルが幅 $0.1 \sim 1 \mu \mathrm{m}$ に集合してフィブリルを構成している。ミクロフィブ リル内は大部分ラメラ構造で約 $10 \mathrm{~nm}$ 厚で積層して いる．高分子配向物はこのフィブリルが構成単位とな り，その長軸をかなり揃えた集合体になったものと考 壳られている，引張り応力はラメラ晶間を結びっける 緊張したタイ分子の分子軸方向の高弾性率部分飞集中 し，その結果，折りたたみループをもつラメラ晶は

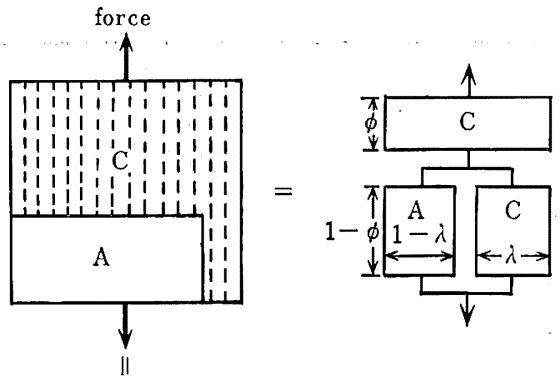

図 1 配向高次構造モデルとカ学等価モデル

$\mathrm{X}$ 線的には上く配向しているにもかかわらず強度的 にはほとんど寄与していない，数％の緊張したタイ 分子が材料の高弾性率発揮にいかに重要であるか力学 モデルを使って解説してみる. 図1は配向結晶相, 無 配向非晶相と緊張したタイ分子から構成された高次構 造モデルと力学等価モデルである7，配向方向の弾性 率, $E_{/ /}$は結晶分子軸方向, $E_{\mathrm{c} / /}$ と非晶相の弾性率, $E_{a}$ とから式 (6) を使って，計算できる.

$$
E_{/ /}=\left\{\frac{1-\phi}{(1-\lambda) E_{a}+\lambda E_{\mathrm{c} / /}}+\frac{\phi}{E_{\mathrm{c} / /}}\right\}^{-1}
$$

$\mathrm{PE}$ を例にとると，室温は主分散温度域より十分高温 であるので $E_{a}=0.01 \mathrm{GPa}, E_{\mathrm{c} / /}=250 \mathrm{GPa}$ としてよ い. 結晶分率, $\phi$ を変数としタイ分子分率 $\lambda$ 飞対し $\tau E_{/ /} / E_{\mathrm{c} / /}$ の值求めてみる. $\phi=0.9$ (結晶化度) の とさ $\lambda=0.02,0.05,0.10$ 飞対して $E_{/ /} / E_{\mathrm{c} / /}$ はと叔 ぞれ，0.17，0.34，0.53 となる。す小わち，䇣張夕 イ分子がわずか $2,5,10 \%$ あるだけで $E_{/}$はとれぞ れ，43，85，133 GPa と高弾性率を示すこととなる. 10\%のタイ分子が存在するだけで理論的に期待され る弾性率の約 $50 \%$ にも達する。

\section{4. 高強度, 高弾性率をもつ高分子 配向試料の製造法}

\section{4-1. 希薄溶液からの配向結晶化法}

高密度 PE のキシレン希薄溶液を同心円筒の間隙に 入れ, $373 \mathrm{~K}$ 以上で溶液に高速セン断応力をかけ, 内 円筒表面上飞 $\operatorname{shish}($ 串) - kebab(肉) 構造の結晶化物 を析出させる ${ }^{8)}$. 希薄溶液の配向結晶化では, 溶液中 でいったん伸長された高分子鎖がランダム状態に戻ら ないようセン断をかけ続け結晶化させることが重要 になる．織維核が内円筒壁面上飞発生すると，その側 面方向にセン断勾配が現われ，側面方向沿った分子 鎖配向と結晶成長速度が低下する，他方，繊維結晶核 の先端では伸長勾配は著しく増加し，shish-kebab 㵶 維が長さ方向沿って成長促進される. shish-kebab 構造は幅 $100 \mathrm{~nm}$ の micro shish-kebab 上飞数 $\mu \mathrm{m}$ 幅のラメラ晶が物理的に付着した高次組織である。 


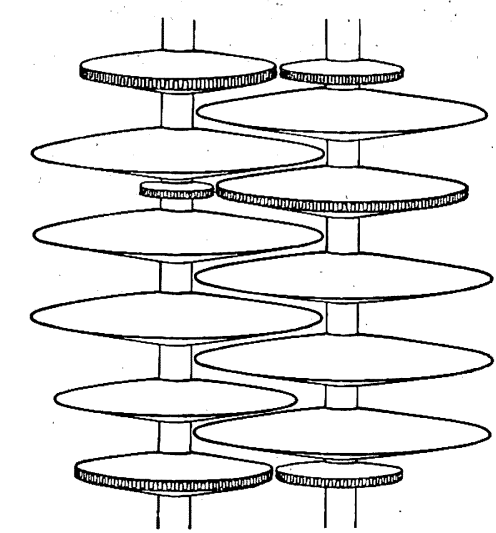

図 2 capillary blockage 法により形成された 配向高次構造

た micro shish-kebab は幅 $15 \mathrm{~nm} の$ 伸びきった分 子鎖の shish とこれに分子的に直接結合したラメラ 晶の kebabから構成されている。それれ党，kebabが 融解している平衡融解温度以上の高温域で配向結晶化 すれば， shish のみから構成される超高弾性率 PEの 開発が可能となる。この可能性は PE のキシンン溶液

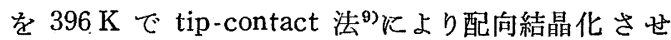
ることにより実現された， tip-contact 法は micro shish-kebab 瀻維の結晶化核となる瀻維核を回転同筒 表面上に付着させ，他端は巻き取りドラムに巻き付け る. tip-contact 法では，回転同筒上に接触した繊維 先端のみで結晶成長が起こり，micro shish-kebab 瀻 維を連続的に生産することが可能となる。

\section{4-2. capillary blockage 法}

Keller $5^{103}$ 性 capillary blockage 法という溶融物 の配向結晶化法と高圧結晶化法を組み合せた操作によ り高弾性率高分子を得た。 ピストンで capillary 中に $411 \mathrm{~K}$ の溶融状態の $\mathrm{PE}$ を押出して分子鎖配向を行な い, $2 \sim 3 \%$ の配向結晶化㵶維核を形成させ, その後, capillary の出口を閉じ, capillary の圧力を $10 \mathrm{MPa}$ から $200 \mathrm{MPa}$ まで上昇させた。圧力上昇飞より $\mathrm{PE}$ の融点は上昇し, 過冷却度が大きくなるため絨維核を 中心に結晶化しているラメラ晶厚は次第に減少する.

図2のようにフィブリル表面から成長するラメラ晶厚 は $40 \mathrm{~nm}$ であるのに対して, ラィラ成長先端では約 4 $\mathrm{nm}$ となり，先細りのラメラ晶の積層組織が得られる. 隣接フィブリルから成長した先細りラメラ積層組織が 互いに齒車がかみ合らように大り組み、ラメラ晶も荷 重を分担し受け持つことができる。この高圧結晶化物 には shish は約 $2 \sim 3 \%$ みであるが, 残りの互い に入り組んだラメジ晶の積層組織を利用し, $100 \mathrm{GPa}$ の高弾性率を有する配向物を得た点, 興味ある加工法 であるままたラメラ晶がよく発達しているため, 超延
伸法によって調製された試料と比較して非常に透明 で, 熱収縮は小さい。

\section{4-3. 超延伸法}

Ward ら ${ }^{11}$ は, 種々の分子量の高密度 $\mathrm{PE}$ 試料を 用い, 分子量, 分子量分布, 結晶化度, モルホロジー と延伸性の関係を検討し，最大延伸比を 35 まで向上 させることに成功し，70 GPa の高弾性率 PE 織維を得 $た^{122}$. Ward らは長周期 $L$, 分子軸方向の結晶の厚み $\bar{D}_{002}$ や結晶化度 $\chi$ などの高次構造パラメータと, 瀻 維軸方向の弾性率の温度依存性とを比較し, 高弾性率 の発現はラメラ晶を貫通している 約 40〜50 nm . 長の intercrystalline bridge であると指摘した。彼らは， intercrystalline bridge を強化材とする複合モデルを 考兄, 図 1 の配向物高次組織の力学モデルを用いて弾 性率を評価した ${ }^{13)}$. intercrystalline bridge がラメラ 晶間の非晶領域を貫通する面積分率を $p$ とすると，

$$
p=\frac{\bar{D}_{002}-L}{\bar{D}_{002}+L}
$$

で表わされる， $、$ 緩和温度域 $(150 \mathrm{~K})$ では，非晶鎖 のミクロブラウン運動は完全に凍結されているので, 力学的には等方性結晶相と同樣な役割を果たすと仮定 すると, 上記力学モデルより導かれる分子鎖方向の弾 性率 $E_{/ /}$と理論弾性率 $E_{\mathrm{c} / /}$ の比は, intercrystalline bridge の体積分率に比例することとなる.

$$
\frac{E_{/ /}}{E_{\mathrm{c} / /}} \simeq V_{f}=\chi p(1-2 p)
$$

式 (8) の左辺は力学測定上り, 右辺以構造論的測定 に上り独立に求まる。式 (8) が成立することは，超延 伸配向物が intercrystalline bridge を強化材とする 繊維強化複合モデルで説明できることを示している。 すなわち, 弾性率汇関する力学特性が結晶相の連続性 に由来していることを示唆している ${ }^{14)} . \bar{D}_{002}$ の大き さとその分布は電子線回折, 広角 $\mathrm{X}$ 線回折户超延伸 物の硝酸エッチングによる GPC 測定より評価でき

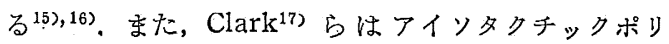
プロピレン $(i-\mathrm{PP})$ を $403 \mathrm{~K}$ で最高約 25 倍まで二 段階延伸し， $23 \mathrm{GPa}$ の弾性率を持っ $i$-PP 配向物を 得た. Ciferri ら ${ }^{18}$ は,ナイロン $6(\mathrm{Ny} 6)$ 飞少量の 塩化リチウムを溶融混合した試料を 5 倍に延伸し, そ の後熱処理を行ならことによって，通常の配向物の 4 倍飞相当する $13 \mathrm{GPa}$ の弾性率を得ている。

\section{4-4. Zone-drawing むたは Zone-annealing 法}

木方ら ${ }^{199}$ は，加熱試料のネッキング部のみ限って 延伸を行なら zone-drawing 法を開発した. 延伸温度 $383 \mathrm{~K}$ で延伸比 36 のとき, 弾性率 $73 \mathrm{GPa}$ の高密度 $\mathrm{PE}$ 配向物を得た．Zone-drawing 法では試料自身の 延伸速度と加熱部の移動速度の組み合わせにより延伸 
比をかなり自由に変化させることが可能である.Zonedrawing 法の場合飞は, 高分子鎖は定常状態で延伸 され，延伸前後の熱処理効果を無視することができ， 延伸時仙出現する伸び切り鎖を有効に凍結することが できる. 功刀ら ${ }^{20} は$ は, zone-annealing 法により弾性 率 $16.5 \mathrm{GPa}$, 強度 $1.0 \mathrm{GPa}$ の $\mathrm{Ny} 6$ 繊維を得てい る. 第 1 段の延伸ではできるだけ結晶化しない高配向 物を調製し, 第 2 段の熱処理で高配向の結晶相を形成 させる。また，彼らは結晶弾性率の $20 \%$ に相当する $21.4 \mathrm{GPa}$ のポリエチレンテレフタレート織維が得ら れると報告している。

\section{4-5. 固体押出し法}

Porter ら ${ }^{21}$ は, $407 \mathrm{~K}$ で $0.23 \mathrm{GPa}$ の 圧力条件下 で, instron capillary rheometer を用い固体 PE を 押出した. 延伸比 36 の場合, 伸び切り鎖が 15〜18\% 存在する弾性率 $70 \mathrm{GPa}$ の配向物が得られた。ささらに 彼ら ${ }^{22}$ は radial-compression 法といら新しい方法 で延伸比 40 45, 弾性率 $62 \mathrm{GPa}$ の $\mathrm{PE}$ 配向物を得 ている.この方法は PE の円筒炕約 5 倍に伸張させ たスパンデックス系を堅く巻きつけ，高温に加熱した 時の采の収縮力によって PE の円筒の半径方向に圧力 を生じさせて配向させようとするものである. Porter らは, アイソタクチックポリスチレンフィルムを $\mathrm{PE}$ あるいは $i$-PP のビュレット間にはさみ, 固体共押出 しにより結晶弾性率の約 $40 \%$ に担当する $45 \mathrm{GPa}$ の 配向陚料を得ている ${ }^{28)}$.

\section{4-6. ダイス延伸法}

ダイスからビニレットを強制的に引張り出し, 高配 向瀻維を調製する方法である ${ }^{24)}$. 固体押出法と比較し て延伸に伴う試料直径の減少のためダイス表面と試料 との接触面積が少なくなり, 低応力で高配向試料が連 続的汇調製できる点有利である。

\section{5. 超高分子量ポリエチレンの 高弾性率配向物の製造}

表1から明らかなように，現在むで達成されている 高分子材料の弹性率出よび強度は理論値よりははるか 飞低い：この事実は高分子鎖のからみ合いのため共有 結合力が力学的に有効に利用されていないことを意味 している. 強い分子間水素結合を形成寸る Ny 6 の高 弾性率試料が得にくいのも同様な理由からであるう.

高分子㠜集体中では分子鎖どうしのからみ合い性本質 的に存在するのでからみ合いを適当に注どき，結晶欠 宿のない高配向繊維を製造することは非常に困難であ る. 単結晶マットの高延伸性は分子鎖どうしのからみ 合いを非常に減少させていることに由来する. 延伸, 配向操作以前に，くしで髮の毛をすくょうに高分子鎖
どらしのからみ合い点をできるだけ少なくして特く ことが, 力学的極限值を得るために重要な前処理法で あ万う. 特に, 分子量 100 万以上の超高分子量の場合 飞は, からみ合いも著しく多く, 高強力, 高弾性率配 向物を調製するには，4節で述べた加工法以外に一工 夫必要である.

Pennings ${ }^{25)}$ らは, ゲル紡系, 熱延伸法により超高 分子量 PE の高弾性率配向物を得ている. 彼らは, $\bar{M}_{n}=20$ 万, $\bar{M}_{w}=150$ 万の $\mathrm{PE}$ の $2 \mathrm{wt} \%$ のデカリ ン溶液を $423 \mathrm{~K}$ で調製した。この高粘度溶液を 393 $\mathrm{K}$ で毛細管から押出紡糸し、デカリンを含んだまま 室温まで急冷し，373〜 413 K で 32 倍まで熱延伸し て弾性率, $E=90 \mathrm{GPa}$, 破断強度, $\sigma_{b}=3 \mathrm{GPa}$ の配向 物を得ている. 彼らは, さらに $\bar{M}_{w}=400$ 万の $\mathrm{PE} て ゙$ $E=120 \mathrm{GPa}, \sigma_{b}=3.7 \mathrm{GPa}$ の值を報告している ${ }^{26)}$. 溶 媒を含んだ紡系試料はわずかな数の分子鎖からみ合い 点をもつランダムコイルの凝集体である．この凝集体 を急冷すると分子内あるいは分子間のからみ合い点を そのまま残したま微結晶が形成され，物理的な橋か け点として延伸配向効果に有効飞働く，そのため, 超 高分子試料の場合でも非常飞延伸性がょく, 高い力学 物性值が得られることがゲル紡系の特徽である. 溶媒 は可塑剤的な役割というょりむしろからみ合いを減少 させるのに役立っている．Pennings らは，膨潤実験 上り, 橋かけ点密度を求め, 高分子鎖 1 本につき 2 個 の橋かけ点が存在する場合, 熱延伸により張力が分子 鎖に有効にかかることを明らかにした ${ }^{27)}$. 高弾性率, 高強度絨維を得るためには $\bar{M}_{n} か ゙ 22,000$ 以上必要で あるといら事実は，延伸効果住対するからみ合い点の 重要さを示唆している ${ }^{28)}$. 固体膜中のようにからみ合 い点が多い場合には，からみ合い点が局所的な応力集 中点となり，低延伸倍率でも分子鎖が切断する ${ }^{29)}$. また, Pennings らは $\bar{M}_{w}=400$ 万の $\mathrm{PE}$ の希薄溶液 を二重円筒内で配向結晶化させ tip-contact 法飞より shish-kebabを調製し， $423 \mathrm{~K}$ で 5 倍延伸し， $E=119$ $\mathrm{GPa} ， \sigma_{b}=4.7 \mathrm{GPa}$ の配向物を得ている ${ }^{30)}$.

\section{6. 化学的手法による高強度, 高弾性率 高分子材料の開発}

芳香族・ポリアミド，ーポリイミドなどの主鎖に芳香 族環を持つ高分子は宇宙工学分野で使用する耐熱性高 分子として研究されてきたが, 今日では高強度高弹性 繊維として期待されるようになってきだ1). 特に, 全 芳香族ポリ( $p$ ーアミド) と対するへキサメチルホスホ ールアミドや N-メチルピロリドンなどの新規溶剤の 開発と低温溶液重合法の成功により㵶維やフィルムに 成形可能な高分子量全芳香族ポリアミドの重合が可能 
となってきた．また，全芳香族ポリアミドは分子鎖の 剛直性のため, 高濃度域で液晶相となり, 液晶紡糸技 術の進歩によって一躍耐熱性あるい性高強度高弾性高 分子として研究者の興味を引くようになった.

一般に, 高強度, 高弾性率織維形成可能な高分子は, 主鎖 や- $\mathrm{CH}=\mathrm{N}$ 一の結合単位をもち, その両端に $p$-配 位のベンゼン環を持つため, 分子鎖は折りたたむこと が不可能な剛直性高分子となる. 剛直性高分子の代表 としてポリ ( $p$ フェニレンテレフタルアミド)(PPTA) があげられ，1971〜1973 年に Du Pont 社が Kevlar, aramid 繊維として発表した. Kevlar 注鋼と比較し て比重は $1 / 6$ 程度であるが, 鋼の弾性率と匹敵しうる ほどの理論弾性率 $153 \mathrm{GPa}$, 理論強度 $30 \sim 40 \mathrm{GPa}$ をもつ。

近年, 力学的特性で金属に匹敵するポリ $(p \cdot フ ェ ニ$ レンベンゾビスチアゾール) (PBT) が注目されてき た. PBT 繊維は液晶紡系され, その熱処理瀻維は $E=280 \mathrm{GPa}, \sigma_{b}=2.7 \mathrm{GPa}$ である ${ }^{32,33)}$. その弾性率 は, $\mathrm{Fe}$ のひげ結晶の $E=295 \mathrm{GPa}$ 飞, 強度は $\mathrm{Cu}$ の ひげ結晶の $\sigma_{b}=2.94 \mathrm{GPa}$ に十分対抗しうる.

\section{7. 剛直分子を強化材とする分子複合材料の設計}

PBT を強化材とし, ポリ $(2,5$ ベンゾイミダジー ル) (PBI) をマトリックスとする分子複合系が米空軍 によって精力的化研究されている. PBT とPBI との 間の相分離をできるだけ避けるために, PBT/PBI (30/70) のメタン硫酸等方性溶液を水中で急激炕凝固 させ, 緘維あるいはフィルムを調製している.溶液押 出しフィルムは $300 \%$ をで延伸可能である. 形態学的 観察よりアスペクト比 200 の剛直 PBT 分子が分子状 に近い状態 $(6 \mu \mathrm{m}$ 径のフィブリル) で分散している ことが確認された，配向試料を $823 \mathrm{~K}$ で熱処理する と $E=120 \mathrm{GPa}, \sigma_{b}=1.4 \mathrm{GPa}$ となり, 強力鋼に匹敵 する力学特性を持つことが明らかとなった ${ }^{34)}$.

高柳らは PPTA/Ny 6 分子複合系の複合強化機構 について検討した ${ }^{35}$. カットは溶媒蒸発法で Ny 6 を 結晶化させた PPTA 繊維/Ny 6 とガラス瀻維/Ny 6 系の走查型電子顕微鏡写真である.ガラス繊維上では, Ny 6 単独の場合と同様に三次元球晶状に結晶化する. 他方, Ny 6 は, PPTA 繊維の周り飞直径約 $50 \mathrm{~nm}$ の 円筒状に結晶化する。構造論的解析より, PPTA 瀻維 表面が Ny 6 の結晶核剤として作用し, 絨維表面近傍 では PPTA と Ny 6 の水素結合方向を揃えたェピタ キシャル結晶化が起こっている. Ny 6 ラメラ晶は, PPTA 繊維軸飞沿って垂直に積層した複合化構造を
していることが明らかとなった。 ポリ(p-ベンズアミ ド) (PBA)/Ny 6 分子複合系の凍結破断面の表面レプ リカ電子顕微鏡写真より, PBA が 10 30 nm 程度の ミクロフィブリルとなり， Ny6 マトリックス中に分 子状に近い状態で分散していることが明らかとなっ $た^{86)}$. また結晶化の動力学的解析より; PPTA/Ny 6 と同様に PBA が Ny 6 の不均一核生成の造核剤とし て作用していることは明らかである。

\section{8. 終りに}

高分子鎖 1 本の強度拈よび弾性率の限界は共有結合 から容易飞予測することが可能である。しかし，高分 子鎖の㠜集物の場合には，結晶化度，分子量，分子量 分布, 分子鎖の配向度など力学的性質に関与する制御 因子があまりにも複雑にからんでいるので, 高強度, 高弾性率高分子の製造法に対する簡単な解決策はまだ 不明である. 分子量分布が狭い超高分子量物を用い, 変形配向操作の前段階でできるだけからみ合いの少な い高次組織にした後に，超高延伸することにより，超 高強度, 超高弾性率配向試料が調製できる. 分子量が 有限であるための分子鎖のすべりや分子鎖末端による 構造欠陌は, 高配向試料のフィブリル間に $\gamma$ 線照射や その他の化学的手法に上り, 橋かけを促進すれば熱的 安定な極限材料が製造できるであるう.

\section{文献}

1）高柳素夫：高分子, 27,84 (1978)

2) 伊藤泰輔：高分子, 31，890 (1982)

3) 井口正俊：高分子, 31，925 (1982)

4) L. R. G. Treloar: Polymer, 1, 95 (1960)

5) P. I. Vincent: Polymer, 13, 558 (1972)

6) A. Peterlin: Colloid Polym. Sci., 253, 809 (1975)

7) M. Takayanagi, K. Imada, T. Kajiyama: J. Polym. Sci., C, 15, 263 (1966)

8) M. R. Mackley, A. Keller: Phil. Trans. Roy. Soc., (London), 278, 29 (1975)

9) A. Zwilnenburg, A.J. Pennings: Colloid. Polym. Sci., 253, 452 (1975); 254, 868 (1976)

10) A. Keller, J.A. Odell: J. Polym. Sci., Polym. Symp., 63, 155 (1978)

11) G. Capaccio, I. M. Ward: Polymer, 15, 233 (1974)

12) G. Capaccio, T. M. Crompton, I. M. Ward: Polym. Eng. Sci., 18, 53 (1978)

13) A.G. Gibson, G. R. Davis, I. M. Ward: Polymer, 19, 683 (1978)

14) G. Capaccio, J. Clemente, P. J. Hine, I. M. Ward: J. Polym. Sci., Polym. Phys. Ed., 19, 1435 (1981)

15) J. Clemente, R. Jakeways, I. M. Ward: Polymer, 19, 639 (1978)

(352 頁一続く) 
副資材を組み合わせて，改良を試みている。

上述した過酷な複合環境での実験は, 費用, 時間,

労力がかかるので, 実験例が少なく, 今後より一層の データ蓄積の努力が望ふれている.

\section{文献}

本論の内容は広範囲なので, どんな諭文がぞこに出 ているかを知ることは，大変な労力を要する，そのた めには, “極低温データ・ブック・ガイド”[柳井正誼; 低温工学, 12 [3] 109 (1977)] は大変役立つ. 本論つ 読者としては専門でない方が压倒的に多いと思われる のでなるべく研究諭文でなく，“解説”を参考文献 にあげた。また，いろいろの雑誌から引用すると，参 考にするとき不便であるので，ここでは，できるだけ “低温工学”から引用した。

1) 津谷和男 : 低温工学, 11 [4] 149 (1976)

2) 石井格, 野口卓也: 同上, 10 [5] 161 (1975)

3) 西嶋茂宏, 岡田東一：同上, 14 [3] 99 (1979)

4) 津谷和男 : 同上, 12 [6] 215 (1977)

5) R.P. Reed, R.E. Schramm, A.F. Clark: Cryogenics, 13 [Feb.] 67 (1973)

6) ICEC9-ICMC 展示委員会：低温工学, 17, [別 冊] 5 (1982)

7) 十亀英司 : 同上, 15 [2] 84 (1980)

8) 橋井一雄 : 同上, 11 [5] 201 (1976)
9) 塩谷 光 : 同上, 17 [5] 275 (1982)

10) 村上正秀 : 同上, 17 [2] 65 (1982)

11) 福山秀敏 : 同上, 17 [3] 143 (1982)

12) 蓮尾信也：同上, 16 [1] 1 (1981)

13）川手剛雄, 堀内健文, 園井英一, 多井勉: 同上, 14 [4] 164 (1979)

14) 稲井信彦: 同上, 13 [2] 53 (1977)

15）低温工学, 17 [6], 強化プラスチック製クライオ スタット, 住友 (p. 322), 東芝 (p. 326), ほく さん（p. 332）

16) 梅田政一：低温工学, 13 [4] 187 (1978)

17) 等々力達: 同上, 9 [5] 209 (1974)

18）浮上式鉄道の超電導極低温技術特集, 同上, 16 [5] 255 (1981)

19) 岩本雅民：同上, 16 [2] 69 (1981)

20) 堤 泰行, 斡 芳彰, 坂元 健 : 同上, 11 [3] 95 (1976)

21) 石橋健二, 小林次雄, 工藤 昇, 小林嶺夫 : 同上, 15 [6] 349 (1980)

22) 石井 格 : 同上, 16 [6] 357 (1981)

23) 西嶋茂宏, 岡田東一：同上, 14 [3] 111 (1979)

24）上田真三, 西嶋茂宏, 岡田東一：同上, 16 [6] 315 (1981)

25) 加藤輝雄, 高村三郎 : 同上, 13 [5] 243 (1978), 14 [4] 179 (1979); 15 [3] 173 (1980)

26) M.J. Chant: Cryogenics, 7, 351 (1967)

\section{(341 頁より続く)}

16) G. Capaccio, I. M. Ward: J. Polym. Sci., Polym. Phys. Ed., 20, 1107 (1982)

17) W. N. Taylar, E.S. Clark: Polym. Eng. Sci., 18, 518 (1978)

18) D. Acierro, F.P. Lamantia, G. Pdizzotti, G. C. Alfonso, A. Cefferi: J. Polym. Sci., Polym. Lett. Ed., 15, 323 (1977)

19) H. Kiho, K. Asai: J. Macromol. Sci.-phys., in press

20) T. Kunugi, I. Akiyama, M. Hashimoto: Polymer, 23, 1193 (1982)

21) N.E. Weeks, R.S. Porter: J. Polym. Sci., Polym. Phys. Ed., 13, 2049 (1975)

22) P.D. Griswold, R. S. Porter, C. R. Desper, R. J. Farris: Polym. Eng. Sci., 18, 537 (1978)

23) B. Appelt, R.S. Porter: J. Appl. Polym. Sci., 26, 2841 (1981)

24) P.S. Hope, A. Richardson, I. M. Ward: $J$. Appl. Polym. Sci., 26, 2879 (1981)

25) P. Smith, P.J. Lemstra, B. Klab, A. J. Pennings: Polym. Bull., 1, 733 (1979)

26) B. Kalb, A.J. Pennings: J. Mater. Sci., 15, 2584 (1980)

27) J. de Boer, A.J. Pennings: Polym. Bull., 2,
309 (1982)

28) W. Wu, W. B. Black: J. Polym. Sci., Polym. Phys. Ed., 18, 751 (1980)

29) L. Fischer, R. Haschberger, A. Ziegeldorf, W. Ruland: Colloid Polym. Sci., 260, 174 (1982)

30) J. C. M. Torfs, A. J. Pennings: J. Appl. Polym. Sci., 26, 303 (1981)

31) A. Blumstein: Liquid Crystalline Order in Polymers, Academic Press (1978)

32) S. R. Allen, A. G. Filipov, R. J. Farris, E. L. Thomas, C.P. Wong, G.C. Berry, E.C. Chenevey: Macromolecules, 14, 1135 (1981)

33) S. R. Allen, A. G. Filipov, R. J. Farris, E. L. Thomas: J. Appl. Polym. Sci., 26, 291 (1981)

34) W. W. Adams, T.E. Helminiak, A. Viswanathan, W.F. Hwang, D.R. Wiff: IUPAC Macro 82 Preprint, (1982) p 827, p 828

35) T. Kajiyama, T. Oono, F. Kumamaru, M. Takayanagi: Polym. Compos., 4, 135, 141 (1983)

36) 甲斐 丘, 梶山千里, 高柳素夫 : 高分子論文集, 39, 441 (1982) 